\title{
LEMBAGA PENDIDIKAN ISLAM DALAM TELAAH LINGKUNGAN STRATEGIK
}

\author{
Muhamad Khoirul Umam \\ STAI Badrus Sholeh Kediri \\ khoirulumam2426@gmail.com
}

\begin{abstract}
ABSTRAK
Lingkungan lembaga pendidikan pada dekade terakhir ini dihadapkan pada berbagai perubahan, gejolak dan kemajuan yang sering kali sulit diprediksi baik karena pergolakan maupun karena ketidakpastian yang dialami, untuk itu diperlukan antisipasi dini terhadap perubahan lingkungan. Tujuan penelititan ini menganilisis bagaimana menghadapi perubahan dan ketidakpastian lingkungan lembaga pendidikan mau tidak mau (inevitable) harus melakukan tiga hal sebagai berikut: 1) Berfikir strategis yang tidak pernah dilakukan sebelumnya, 2) Menerjemahkan inputnya untuk strategi yang efektif guna menanggulangi lingkungannya yang telah berubah, 3) Mengembangkan alasan yang diperlukan untuk meletakan landasan bagi pemakaian dan pelaksanaan strateginya. Sehingga memunculkan pertanyaan penelitian bagaimana pengenalan lingkungan strategik, telaah lingkungan strategik, tujuan dan peran telaah lingkungan strategik, model analisis lingkungan strategik di wilayah pendidikan Islam. Hasil penelitian ini menejelaskan Analisa TOWS Matrix lebih memastikan kita dapat memperhitungkan dan memanfaatkan dengan baik setiap peluang di luar untuk peningkatan bisnis. Di saat bersamaan kita juga dapat mengetahui dan memanfaatkan potensi internal. Dengan menganalisa eksternal tersebut (TOWS Matrix) kita juga mampu mengantisipasi tantangan dari setiap perubahan eksternal, bahkan mengubahnya (tantangan) menjadi peluang baru.
\end{abstract}

Kata Kunci: lembaga pendidikan, lingkungan strategik, analisis lingkungan

\section{PENDAHULUAN}

Pendidikan oleh UU No. 20 Tahun 2003 pasal 1 diartikan sebagai usaha sadar dan terencana untuk mewujudkan suasana belajar dan proses pembelajaran agar peserta didik secara aktif mengembangkan potensi dirinya untuk memiliki kekuatan spiritual keagamaan, pengendalian diri, kepribadian, kecerdasan, akhlak mulia, serta keterampilan yang diperlukan dirinya, masyarakat, bangsa dan negara. Usaha sadar seperti yang dimaksud dalam undang-undang tersebut diimplementasikan dengan membentuk lembaga pendidikan formal dan lembaga pendidikan non formal. Sebagai implikasinya pendidikan juga memiliki fungsi untuk menjadikan manusia sebagai mahluk yang beradab dan memiliki kemampuan dalam menghadapi seleksi alam dalam perjalananan hidup. ${ }^{1}$

Pendidikan yang berada dalam sebuah lembaga akan dikelola oleh sumber daya yang beragam dalam upaya pencapaian tujuan pendidikan itu sendiri. Dalam pengertian tersebut menunjukan bahwa diperlukan fungsi-fungsi manajemen dalam pengelolaan pendidikan. Empat fungsi dalam manajemen tersebut adalah perencanaan, penglembagaan, pelaksanaan

\footnotetext{
${ }^{1}$ UU Sisdiknas No. 20. Tahun 2003
} 
dan pengawasan yang dilakukan untuk mencapai tujuan pendidikan. ${ }^{2}$ Sehingga keempat fungsi ini dibutuhkan dalam upaya mencapai tujuan pendidikan, tanpa mensampingkan faktor lingkungan sebagai penentu keberhasilan pencapaian hasil.

Lingkungan lembaga pada dekade terakhir ini dihadapkan pada berbagai perubahan, gejolak dan kemajuan yang sering kali sulit diprediksi baik karena pergolakan maupun karena ketidakpastian yang dialami, untuk itu diperlukan antisipasi dini terhadap perubahan lingkungan. Menghadapi perubahan dan ketidakpastian lingkungan ini lembaga mau tidak mau (inevitable) harus melakukan tiga hal sebagai berikut: 1) Berfikir strategis yang tidak pernah dilakukan sebelumnya, 2) Menerjemahkan input-nya untuk strategi yang efektif guna menanggulangi lingkungannya yang telah berubah, 3) Mengembangkan alasan yang diperlukan untuk meletakan landasan bagi pemakaian dan pelaksanaan strateginya.

Lembaga pendidikan juga harus memperhatikan lingkungannya baik internal maupun eksternal sebagai bagian dari upaya pencapaian tujuannya dengan cara menganalisa lingkungan strategisnya (strategic analysis). Hal ini dimaksudkan untuk dapat mengetahui pengaruh-pengaruh kunci serta pemilihan strategi yang sesuai dengan ketidakpastian, perubahan, dan tantangan yang berasal dari lingkungan.

Dari latar permasalahan diatas peneliti memfokuskan pertanyaan penelitian tentang bagaimana pengenalan lingkungan strategik, telaah lingkungan strategik, tujuan dan peran telaah lingkungan strategik, model analisis lingkungan strategik di wilayah pendidikan Islam.

\section{METODE PENELITIAN}

Jenis dari penelitian ini adalah Library Research ${ }^{3}$, dengan pendekatan penelitian teks literasi serta fenomena lapangan, teknik penelitian mengumpulkan data melalui metode dokumentatif-observatif. Kemudian setelah data-data terkumpul, dianalisis melalui analisis isi dan analisis kritis. ${ }^{4}$

\section{HASIL PENELITIAN DAN PEMBAHASAN}

\section{Pengenalan Lingkungan Strategik}

Sekarang dan pada masa yang akan datang, lembaga dihadapkan pada situasi dan kondisi yang menuntut adanya pergeseran paradigma dalam memandang lingkungan sekitarnya. Lingkungan telah berubah tidak ada lagi terminologi stabilitas dalam lingkungan bisnis global dewasa ini, ${ }^{5}$ yang terbentang luas saat ini hanyalah stabilitas yang bersifat semu yang harus disikapi secara kritis oleh lembaga.

Sembiring dalam artikelnya menegaskan bahwa salah satu yang perlu dikaji manajemen adalah perubahan lingkungan strategik, baik dalam skala global maupun domestik. Pada skala global fenomena globalisasi merupakan indikasi kuat perubahan

\footnotetext{
${ }^{2}$ Hanafi, M. (2015). Manajemen.

${ }^{3}$ Kuhlthau, C. C. (1994). Teaching the library research process. Rowman \& Littlefield.

${ }^{4}$ Arikunto, S. (2006). Metodelogi penelitian. Yogyakarta: Bina Aksara.

5 Umam, M. K. (2017). ANALISIS LINGKUNGAN STRATEGIK DALAM CORAK
} PENYELENGGARAAN PENDIDIKAN ISLAM. Jurnal al Hikmah, 5(1), 1-8. 
lingkungan strategis. Globalisasi merupakan proses di mana masyarakat dunia semakin terhubungkan (interconected) satu sama lainnya dalam berbagai aspek kehidupan, seperti budaya, ekonomi, politik, teknologi, dan lingkungan. Dunia berubah menjadi sebuah pasar global, bukan hanya untuk barang dan jasa, melainkan juga penyedia modal dan teknologi. ${ }^{6}$

Lingkungan bisnis telah dan sedang mengalami perubahan signifikan. Perubahan tersebut diperkirakan akan semakin kompleks dan sulit untuk diprediksi. Dengan kata lain, lingkungan bisnis (akan) semakin turbulen. Globalisasi merupakan salah satu penyebab utama semakin turbulennya lingkungan bisnis pada era 1990-an. Globalisasi mencerminkan adanya kesempatan lembaga bisnis untuk berkembang melalui eksploitasi pasar internasional dengan biaya yang lebih efisien. ${ }^{7}$ Kondisi ini sekaligus juga mendorong terciptanya persaingan yang lebih ketat antar lembaga bisnis. ${ }^{8}$ Persaingan yang semakin ketat telah memaksa lembaga bisnis mencari cara baru untuk bisa bertahan. Di samping harus berorientasi pada konsumen (customer), lembaga bisnis harus efisien.

Dalam lingkungan bisnis yang turbulen, perusahaan harus senantiasa melakukan penyindiraan terhadap trend perubahan yang terjadi di lingkungan bisnis dan merespons dengan cepat dan efektif trend perubahan tersebut. ${ }^{9}$ Dalam lingkungan bisnis yang kompetitif produk dan jasa yang dihasilkan oleh produsen hanya dapat dipilih oleh customer jika produk dan jasa tersebut memiliki keunggulan (distinction) dari persaingan. Perubahan lingkungan yang bergejolak (turbulen) dan ketidakpastian (uncertainty) yang bergerak cepat dan tidak menentu mendorong para akademisi, praktisi, birokrat, dan berbagai profesi lainnya untuk berpacu mengembangkan strategi perubahan dan kebijaksanaan antisipatif agar mampu menyesuaikan diri dengan berbagai ragam tuntutan lingkungan.

Lebih lanjut Kenichi Ohmae mengingatkan bahwa saat ini kita memasuki era dunia tanpa batas. Dunia tanpa batas ini ditandai dengan semakin terfokusnya masalah ke dalam 5 C, yakni Customer, Company, Competition, Curency, dan Country. Pentingnya perhatian terhadap aspirasi pengguna jasa, pelanggan atau masyarakat tidak diragukan lagi. Salah satu alternatif paradigma daya saing lembaga, baik privat maupun publik adalah siapa saja yang ingin bertahan dalam persaingan haruslah dapat menyediakan barang dan jasanya yang memiliki nilai tertinggi di mata konsumen. Dengan demikian, lembaga dituntut untuk semakin kritis untuk menyikapi fenomena-fenomena perubahan lingkungan bisnis global yang terjadi dewasa ini agar mampu bertahan hidup (survive) melalui perubahan cara pandang yang dimilikinya terhadap kondisi eksternal dan internal yang ada. Sedemikian cepatnya perubahan yang terjadi pada lingkungan eksternal lembaga akan menghadapkan

${ }^{6}$ Eddy R. Sembiring, Meraih Competitive Advantage Melalui Learning Organization. (Media Akuntansi, 2003), 52-53

${ }^{7}$ Suneki, S. (2012). Dampak globalisasi terhadap eksistensi budaya daerah. CIVIS, 2(1/Januari).

${ }^{8}$ Umam, M. K. (2017, May). Strategi Alternatif Memajukan Lembaga Pendidikan Islam di Pedesaan Berbasis Sekolah Excellent Perspektif Kompetitif Kotemporer. In Proceedings of Annual Conference for Muslim Scholars (No. Seri 2, pp. 769-776).

${ }^{9}$ Umam, M. K. (2018, April). Reconstruction of Integrative Islamic Education in The Transformative Profetical Education Framework. In Proceedings of Annual Conference for Muslim Scholars (No. Series 1, pp. 511-520). 
lembaga pada pertanyaan mengenai keputusan-keputusan strategik apa saja yang dapat dibuat agar dapat selalu kompetitif. ${ }^{10}$

Salusu mengemukakan bahwa lingkungan adalah hal-hal yang mengelilingi dan mempengaruhi perkembangan lembaga, ${ }^{11}$ sedangkan Wahyudi mengemukakan bahwa lingkungan adalah salah satu faktor penting untuk menunjang keberhasilan lembaga dalam persaingan. ${ }^{12}$

Lingkungan lembaga terdiri dari lingkungan internal dan eksternal. Lingkungan eksternal adalah lingkungan yang berada diluar lembaga. Menurut Chuck Williams, lingkungan eksternal adalah semua kejadian diluar perusahaan yang memiliki potensi untuk mempengaruhi perusahaan. ${ }^{13}$ Selain itu T. Hani Handoko, mengatakan bahwa lingkungan eksternal terdiri dari unsur-unsur diluar perusahaan yang sebagian besar tak dapat dikendalikan dan berpengaruh dalam pembuatan keputusan oleh manajer. ${ }^{14}$ Sementara James A.F. Stoner mendefinisikan lingkungan eksternal terdiri atas unsur-unsur yang berada di luar suatu lembaga, yang relevan pada kegiatan lembaga itu. ${ }^{15}$

Lingkungan eksternal dibagi menjadi:

a. Lingkungan eksternal mikro: pelanggan, pesaing, pemasok, pemerintah, lembaga keuangan.

b. Lingkungan eksternal makro: keadaan ekonomi, teknologi, politik hukum, sosial budaya.

Selanjutnya Chuck Williams, menambahkan lingkungan eksternal menjadi lingkungan yang berubah yaitu angka kecepatan dari perubahan lingkungan umum dan khusus perusahaan baik perubahan yang stabil maupun perubahan yang dinamis. ${ }^{16}$ Lingkungan internal adalah kejadian dan kecenderungan dalam suatu lembaga yang mempengaruhi manajemen, karyawan dan budaya lembaga.

Strategi berasal dari bahasa Yunani kuno yang berarti "seni berperang”. Suatu strategi mempunyai dasar-dasar atau skema untuk mencapai sasaran yang dituju. Jadi, pada dasarnya strategi merupakan alat untuk mencapai tujuan. Menurut Stephanie K. Marrus, seperti yang dikutip Sukristono, strategi didefinisikan sebagai suatu proses penentuan rencana para pemimpin puncak yang berfokus pada tujuan jangka panjang lembaga, disertai penyusunan suatu cara atau upaya bagaimana agar tujuan tersebut dapat tercapai. ${ }^{17}$

Selain definisi-definisi strategi yang sifatnya umum, ada juga yang lebih khusus seperti yang dikemukakan dua orang pakar strategi, Hamel dan Prahalad, yang mengangkat kompetensi inti sebagai hal yang penting. Mereka mendefinisikan strategi sebagai berikut:

${ }^{10}$ Gugup Kismono, Perubahan Lingkungan, Transformasi Organisasional dan Reposisi Fungsi Sumber Daya Manusia. Jurnal Ekonomi dan Bisnis Indonesia, Vol 14 No.2, 1999, 62-76

11 J. Salusu, Pengambilan Keputusan Stratejik: untuk Organisasi Publik dan Organisasi Nonprofit, (Jakarta: Grasindo, 2004), 319

${ }^{12}$ A. S. Wahyudi, Manajemen Strategi, (Bina Aksara, 1996), 48

${ }^{13}$ Chuck Williams, Manajemen. ter. (Jakarta: Salemba Empat, 2001), 51

14 T. Hani Handoko, Manajemen, (Yogyakarta: BPFE, 1999), 62

15 James A.F. Stoner, Manajemen. ter. (Jakarta: Erlangga, 1996)

${ }^{16} \mathrm{C}$. Williams, Manajemen, 51

17 Stepphanie K. Marrus, Building the strategic Plan: find, analyzed, and present the right information, (USA: Wiley, 1984) 
"strategi merupakan tindakan yang bersifat incremental (senantiasa meningkat) dan terus menerus, serta dilakukan berdasarkan sudut pandang tentang apa yang diharapkan oleh para pelanggan di masa depan. ${ }^{18}$ Dengan demikian, strategi hampir selalu dimulai dari apa yang dapat terjadi dan bukan dimulai dari apa yang terjadi. Terjadinya kecepatan inovasi pasar yang baru dan perubahan pola konsumen memerlukan kompetensi inti (core competencies). Lembaga pendidikan meskipun merupakan lembaga nonprofit perlu mencari kompetensi inti di dalam kegiatan yang dilakukan".

Sedangkan Miles dan Snow menggambarkan orientasi strategi sebagai suatu cara pengelompokkan pengambilan keputusan oleh sebuah tindakan manajerial atau proses manajerial (termasuk kapabilitas) dengan lingkungan. Kemudian Ansoff mengatakan bahwa strategi itu adalah produk/lingkup pasar, keunggulan kompetitif, dan sinergi. ${ }^{19}$ Hofer dan Schendel menambahkan lagi unsur pertimbangan geografis, "strategi mencakup ruang lingkup, yang dapat diartikan dalam kesesuaian produk atau pasar sesuai dengan wilayah geografis." Selain itu, disepakati juga pentingnya keunggulan kompetitif dan sinergi. ${ }^{20}$

\section{Telaah Lingkungan Strategik}

Aris Widodo menjelaskan pengertian analisis lingkungan stategis adalah menyusun asumsi-asumsi strategis dan mengujinya dengan visi dan misi lembaga untuk memperoleh faktor penentu keberhasilan. ${ }^{21}$ Sementara itu, Akdon menjelaskan bahwa tujuan kegiatan telaah lingkungan adalah untuk mengenali kekuatan dan kelemahan internal lembaga dan memahami peluang dan tantangan eksternal lembaga sehingga lembaga dapat mengantisipasi perubahan-perubahan di masa yang akan datang. ${ }^{22}$

Dari dua penjelasan di atas, kita dapat mengambil kesimpulan tetang pengertian telaah lingkungan strategik. Telaah lingkungan strategik adalah kegiatan untuk mengenali kekuatan dan kelemahan internal lembaga serta memahami peluang dan tantangan eksternal, untuk kemudian menyusun asumsi-asumsi strategis dan mengujinya dengan visimisi lembaga untuk memperoleh faktor penentu keberhasilan. Dalam Akdon menyebutkan beberapa manfaat dari telaah lingkungan strategik antara lain: ${ }^{23}$

a. Mendeteksi perubahan-perubahan dan peristiwa-peristiwa penting, khususnya berkaitan dengan bidang sosial, politik, ekonomi, dan kemajuan ilmu pengetahuan dan teknologi.

b. Mendefinisikan tantangan, peluang atau perubahan-perubahan yang diakibatkan oleh peristiwa-peristiwa penting tersebut di atas, terhadap lembaga.

\footnotetext{
${ }^{18}$ G. Hamel dan K. C. Prahalad, Kompetisi Masa Depan, (Jakarta: Bina rupa Aksara, 1995)

${ }^{19}$ Ignor Ansoff, Corporate Strategy, (Harmondsworth: Penguin Books, 1965)

${ }^{20}$ Dan Schendel dan Charles Higgins, Pengambilan Keputusan Stratejik untuk Organisasi Public dan Organisasi, (Jakarta: Grasindo, 1985)

${ }^{21}$ Umam, M. K. (2018, April). Reconstruction of Integrative Islamic Education in The Transformative Profetical Education Framework. In Proceedings of Annual Conference for Muslim Scholars (No. Series 1, pp. 511-520).

${ }^{22}$ Akdon, Strategik Management For Educational Management, (Bandung: Alfabeta, 2007), 107

${ }^{23}$ Ibid., 107
} 
c. Memberikan informasi mengenai orientasi masa depan kepada setiap jajaran pimpinan dan staf.

d. Memberikan sinyal kepada seluruh jajaran tentang apa yang harus diperbuat terhadap lembaga, seperti: mempercepat atau memperlambat proses manajemen, melakukan interaksi dengan instansi lalin, dan lainnya.

Lingkungan strategis dianalisa untuk mengetahui pengaruh-pengaruh kunci serta pemilihan strategi apa yang sesuai dengan tantangan yang datangnya dari lingkungan. Dalam menerapkan telaah lingkungan strategik secara baik dan berhasil, perlu dilakukan beberapa langkah pokok yang harus dilakukan, Bryson mengetengahkan delapan langkah pokok tersebut sebagai berikut: ${ }^{24}$

1. Memprakarsai dan meminta persetujuan terhadap suatu proses manajemen atau perencanaan strategik.

2. Mengidentifikasi mandat institusi atau lembaga.

3. Memperjelas misi dan nilai-nilai institusi lembaga.

4. Menilai lingkungan eksternal yang menyangkut peluang maupun ancaman yang ada

5. Menilai lingkungan internal yang berhubungan dengan kekuatan yanng dimiliki institusi maupun kelemahan yang ada.

6. Mengidentifikasi isu strategis yang dihadapi lembaga menyangkut tujuan, cara, falsafah, lokasi, keakuratan waktu dan kelompok-kelompok yang memperoleh keuntungan atau mengalami kerugian jika strategi baru dijalankan.

7. Merumuskan strategi untuk mengolah atau menangani isu-isu yang ada

8. Menciptakan suatu visi institusi atau lembaga yang efektif bagi masa depan.

Dari delapan langkah pokok tersebut, terlihat bahwa lingkungan eksternal dan internal merupakan langkah penting dalam melaksanakan telaah lingkungan strategik, hal ini juga dapat diterapkan untuk lembaga pendidikan. Manajemen pendidikan dapat menganalisa dan mengkaji lingkungan strategisnya yang terdiri dari lingkungan eksternal dan internal untuk mencapai tujuannya. ${ }^{25}$

Pelaksanaan Telaah lingkungan strategik merupakan bagian dari komponen perencanaan strategis dan merupakan suatu proses untuk selalu menempatkan lembaga pada posisi strategis sehingga dalam perkembangannya akan selalu berada pada posisi yang menguntungkan. Lingkup telaah lingkungan strategik meliputi: ${ }^{26}$

- Analisis Lingkungan Eksternal

- Analisis Lingkungan Internal

24 John M. Bryson, Strategic Planning for Public and Non Profit Organization: A Guide to Strengthening and Sustaining Organizational Achievment, (San Fransisco: Jossey-Bass Publishers, 1995), $55-71$

25 Umam, M. K. (2018). IMAM PARA NABI: MENELUSUR JEJAK KEPEMIMPINAN DAN MANAJERIAL NABI MUHAMMAD SAW. Jurnal al Hikmah, 6(1), 59-74.

26 Umam, M. K. (2019). Penggunaan Metode Jaritmatika Dalam Meningkatkan Motivasi Belajar. Awwaliyah: Jurnal Pendidikan Guru Madrasah Ibtidaiyah, 2(1), 45-68. 


\section{Tujuan dan Peran Telaah Lingkungan Strategik}

Aris Widodo menyebutkan contoh tujuan analisis lingkungan dari beberapa perusahaan, antara lain: ${ }^{27}$

1. Untuk menyediakan kemampuan dalam menggapai masalah-masalah kritis dalam lingkungan bagi manajemen perusahan.

2. Untuk menyelidiki kondisi masa depan dari lingkungan lembaga dan kemudian mencoba masukkannya kedalam pengambilan keputusan lembaga.

3. Untuk mengenali masalah-masalah mendesak yang signifikan bagi perusahaan, dan memberikan prioritas terhadap masalah tersebut, serta mengembangkan sutau rencana untuk menanganinya.

Secara khusus, peran atau fungsi analisis llingkungan bagi tiap lembaga tentu saja berbeda-beda. Namun secara umum jika kita mengacu kepada pendapat Certo dan Peter, maka ada tiga peran utama yang bisa ditemui sehari-hari, yaitu: ${ }^{28}$

\section{Policy-Oriented Role}

Yaitu peran analisis yang berorientasi pada kepada kebijakan manajemen tingkat atas dan bertujuan untuk memperbaiki kinerja lembaga dengan memberikan informasi bagi manajemen tingkat atas tentang kecenderungan utama yang muncul dalam lingkungan. ${ }^{29}$

2. Integrated Strategic Planning Role

Peran ini bertujuan untuk memperbaiki kinerja lembaga dengan membuat manajemen tingkat atas dan manajer divisi menyadari segala isu yang terjadi di lingkungan perusahaan memiliki implikasi langsung pada proses perencanaan.

3. Function Oriented Role

Peran ini bertujuan untuk memperbaiki kinerja lembaga dengan menyediakan infomasi lingkungan yang memberi perhatian pada efektivitas kinerja fungsi lembaga tertentu.

Bryson dalam Akdon, menyebutkan beberapa langkah utama dalam telaah lingkungan strategik, yaitu: ${ }^{30}$

1. Mengidentifikasi Sumber-sumber Untuk Melakukan Scanning

Langkah awal dalam telaah lingkungan adalah melakukan identifikasi berbagai sumber untuk melakukan telaah lingkungan strategik. Sumber-sumber ini pada dasarnya dibagi menjadi tiga level, yaitu task environment, industry/organization environment, serta macro environment. Lebih lanjut disebutkan bahwa task environment adalah sumber yang berkaitan dengan tugas-tugas (tugas pokok dan fungsi). Misalnya individu dalam lembaga, unit lembaga, kapasitas lembaga, serta struktur lembaga. Industry/organization environment berkaitan dengan berbagai

27 Umam, M. K. (2018). STRATEGI INTELEKTUALISASI PROGESIFITAS MANHAJUL AL FIKR KADER AN-NAHDLIYAH.

${ }^{28}$ Samuel C.Certo dan Paul J. Peter, Strategic Management: A Focus on Process, (Singapore: McGraw Hill International Editions, 1990), 10-14

${ }^{29}$ Umam, M. K., \& Kediri, S. B. S. P. (2018). Rekonstruksi Pendidikan Islam Integrasi Dalam Kerangka Pendidikan Profetik Transformatif.

${ }^{30}$ Akdon, Strategik Management For Educational Management, 108-111 
lembaga lain yang memiliki keterkaitan satu dengan yang lainnya baik lembaga publik maupun privat. Macro environment merupakan level yang paling luas. Level ini meliputi sektor sosial, politik, ekonomi serta ilmu pengetahuan dan teknologi, yang dapat memberikan pengaruh terhadap lembaga baik secara langsung maupun tidak langsung. ${ }^{31}$ Dengan mengetahui keberadaan sumber-sumber tersebut akan mempermudah langkah selanjutnya dari telaah lingkungan strategik yaitu scanning terhadap lingkungan internal dan eksternal.

2. Melakukan Scanning Terhadap Lingkungan Internal dan Eksternal

Sebelum suatu lembaga membuat rencana hari depan, lembaga itu harus menentukan di mana ia sekarang berada. Mekanisme yang digunakan untuk mengukur kondisi di dalam dan di luar lembaga dilakukan dengan jalan menjawab "di mana sekarang kita berada" hal itu merupakan penilaian internal dan eksternal lembaga. Inilah inti dari kegiatan scanning terhadap lingkungan internal dan eksternal. Penilaian internal dan eksternal adalah suatu telaah dan identifikasi tentang kondisi internal dan data eksternal, serta faktor yang mempengaruhi lembaga.

Hasil dari kegiatan ini adalah identifikasi berbagai kekuatan dan kelemahan lembaga yang merupakan hasil dari secanning lingkungan internal; dan dari lingkungan eksternal akan diperoleh identifikasi peluang dan tantangan yang dihadapi lembaga.

3. Melakukan Analisis Untuk Menilai Hasil Scanning

Tahap ketiga dari kegiatan telaah lingkungan strategik adalah melakukan analisis terhadap hasil scanning. Hasil dari kegiatan tahap ini adalah penilaian terhadap hasil scanning. Penilalian biasanya difokuskan pada sisi input yang dibutuhkan serta output yang dikeluarkan oleh instansi. Pada sisi input umumnya berupa antara lain: anggaran yang dipergunakan oleh instansi, jumlah pegawai dan aspek lain. Sedangkan pada sisi output, umumnya berupa jumlah dan jenis produk atau jasa yang dihasilkan instansi, jumlah pelanggan yang harus dilayani, dan lainnya. Sementara dari lingkungan eksternal dapat dilakukan penentuan berbagai kejadian diluar instansi yang dapat memberikan pengaruh terhadap lembaga/instansi.

Secara umum, kejadian-kejadian tersebut dapat digolongkan ke dalam kejadian yang berkaitan dengan aspek-aspek ekonomi, politik, sosial, perkembangan teknologi, kebijakan pemerintah dan persaingan.

4. Merumuskan Hasil Scanning Untuk Keperluan Penentuan Action Plan

Dalam kegiatan penyusunan telaah lingkungan internal $=$ PLI $($ SIE $=$ Scanning Internal Environment) dan telaah lingkungan eksternal = PLE $(\mathrm{SEE}=$ Scanning Eksternal Environment) serta Kesimpulan Analisis Faktor Internal = KAFI (IFAS = Internal Factor Analysis Summary) dan Kesimpulan Analisis Faktor Eksternal = KAFE (EFAS = Eksternal Factor Analysis Summary) harus berpedoman pada visi (Vision), Misi (Mission) dan nilai-nilai (Value) yang telah disepakati sebelumnya

${ }^{31}$ Umam, M. K. (2019). Peningkatan Mutu Pendidikan Melalui Manajemen Peserta Didik. Jurnal al Hikmah, 6(2), 62-74. 
dan berlaku di lingkungan lembaga yang bersangkutan. Kesesuaian antara hasil scanning dengan visi, misi dan nilai dalam lembaga merupakan dasar dalam pembuatan action plan sehingga action plan dibuat sesuai dengan keberadaan lembaga.

Telaah lingkungan strategis dilakukan untuk mengidentifikasi berbagai peluang (opportunities) dan ancaman (threat). ${ }^{32}$ Peluang adalah kondisi-kondisi lingkungan umum yang dapat membantu lembaga dapat mencapai daya saing strategis. Sedangkan ancaman adalah kondisi-kondisi dalam lingkungan umum yang dapat mengganggu usaha lembaga dalam mencapai daya saing strategis. Ringkasnya, peluang dalam lingkungan eksternal mencerminkan kemungkinan, sedangkan ancaman adalah kendala potensial.

Hitt et.al. menyebutkan bahwa ada empat komponen dalam analisis eksternal, yaitu; scanning, monitoring, forecasting dan assessing. ${ }^{33}$

Pertama, scanning adalah usaha untuk mempelajari seluruh segmen dalam lingkungan umum. Melalui scanning, lembaga mengidentifikasi sinyal-sinyal awal perubahan yang mungkin terjadi dalam lingkungan umum dan mendeteksi setiap perubahan yang sedang terjadi. Dengan scanning, analis secara khusus berhubungan dengan informasi dan data yang tidak jelas, tidak lengkap dan tidak berkaitan satu sama lain.

Kedua, monitoring adalah kegiatan para analis mengamati perubahan untuk melihat apakah, sebenarnya, suatu kecenderungan yang sedang berkembang. Hal penting untuk suksesnya suatu monitoring adalah kemampuan untuk mendeteksi arti dari setiap kejadian lingkungan. Sebagai contoh, kecenderungan baru dalam hal pendidikan dapat diperkirakan dari perubahan dalam dana dari pemerintah pusat dan daerah untuk lembaga pendidikan, perubahan dalam persyaratan kelulusan di sekolah menengah, atau perubahan isi kurikulum. Dalam hal ini, analis akan menentukan apakah peristiwa yang berbeda ini menggambarkan suatu kecenderungan dalam pendidikan, dan jika memang demikian, apakah data atau informasi lainnya harus dipelajari untuk memantau kecenderungan tersebut.

Ketiga, forecasting adalah kegiatan analis mengembangkan proyeksi tentang apa yang akan terjadi, dan seberapa cepat, sebagai hasil perubahan dan kecenderungan yang dideteksi melalui scanning dan monitoring. Jadi scanning dan monitoring berhubungan dengan apa yang terjadi dalam lingkungan umum pada suatu waktu tertentu.

Keempat, assessing bertujuan untuk menentukan saat dan pengaruh perubahan lingkungan serta kecenderungan dalam manajemen strategis suatu lembaga. Melalui scanning, monitoring dan forecasting, analis dapat mengerti lingkungan umum. Selangkah lebih maju, tujuan dari assessment adalah untuk menentukan implikasi dari pengertian itu terhadap lembaga. Tanpa assessment, analis akan mendapatkan data yang menarik, tapi tanpa mengetahui relevansinya.

${ }^{32}$ Umam, M. K. (2018, April). Reconstruction of Integrative Islamic Education in The Transformative Profetical Education Framework. In Proceedings of Annual Conference for Muslim Scholars (No. Series 1, pp. 511-520).

${ }^{33}$ R. D. Ireland, R. E. Hoskisson \& M. A. Hitt, Manajemen Strategis : Daya Saing \& Globalisasi, Edisi ke-1, (Jakarta: Salemba Empat, 2001) 
Telaah lingkungan strategis juga dilakukan untuk mengidentifikasi berbagai berbagai kekuatan dan kelemahan internal (internal strengths and weaknesses). Kekuatan dan kelemahan internal dilakukan dengan melakukan analisis pengembangan profil lembaga yang mencerminkan kondisi internal dan kemampuan perusahaan dan merupakan hasil analisis internal untuk mengidentivikasi tujuan dan strategi sekarang, serta memerinci kuantitas dan kualitas sumber-sumber daya lembaga yang tersedia. Profil perusahaan menunjukkan kesuksesan perusahaan dimasa lalu dan kemampuannya untuk mendukung pelaksanaan kegiatan sebagai implementasi strategi dalam pencapaian tujuan dimasa yang akan datang. ${ }^{34}$

\section{Model Analisis Lingkungan Strategik}

\section{Analisis SWOT (Strength, Weakness, Opportunity, Threat)}

Analisa SWOT adalah suatu cara untuk mengidentifikasi berbagai faktor secara sistematis dalam rangka merumuskan strategi lembaga. Analisa ini didasarkan pada logika dapat memaksimalkan kekuatan (strength) dan peluang (opportunities) namun secara bersamaan dapat meminimalkan kelemahan (weakness) dan ancaman (threats). ${ }^{35}$

Analisa SWOT mempertimbangkan faktor lingkungan internal strengths dan weakness serta lingkungan eksternal opportunities dan threats yang dihadapi lembaga pendidikan. ${ }^{36}$ Analisa ini membandingkan antara faktor eksternal peluang dan ancaman dengan faktor internal kekuatan dan kelemahan sehingga dari analisis ini dapat diambil suatu keputusan strategi lembaga.

Tahapan dalam analisa SWOT berupa:

a. Pengambilan data yaitu evaluasi faktor eksternal dan internal

b. Analisis yaitu pembuatan matriks internal dan eksternal dan matriks SWOT.

c. Pengambilan keputusan

Pengambilan data dapat dilakukan melalui wawancara ataupun analisis kuantitatif dan cara-cara lain. Tahap berikutnya adalah membuat matriks SWOT hingga terbentuk empat alternatif kemungkinan strategi seperti terlihat dalam gambar berikut:

$$
\text { Gambar 1. Matriks SWOT }
$$

\begin{tabular}{|l|l|l|}
\hline & \multicolumn{1}{|c|}{ STRENGTHS (S) } & \multicolumn{1}{|c|}{ WEAKNESSES (W) } \\
\hline OPPORTUNITIES (O) & Strategi SO & Startegi WO \\
& Menciptakan strategi & Menciptakan strategi \\
& yang menggunakan & yang meminimalkan \\
& kekuatan untuk & kelemahan untuk \\
& memanfaatkan & memanfaatkan peluang. \\
& peluang. & \\
\hline
\end{tabular}

${ }^{34}$ Umam, M. K. (2018, February). Paradigma Pendidikan Profetik dalam Pendekatan Pembelajaran Tematik di Madrasah Ibtida'iyah. In PROCEEDING: The Annual International Conference on Islamic Education (Vol. 3, No. 1, pp. 120-132).

${ }^{35}$ Freddy Rangkuti, Analisis SWOT Teknik Membedah Kasus Bisnis, (Jakarta: PT. Gramedia Pustaka Utama, 1998), 19

${ }^{36}$ Jackson, S. E., Joshi, A., \& Erhardt, N. L. (2003). Recent research on team and organizational diversity: SWOT analysis and implications. Journal of management, 29(6), 801-830. 


\begin{tabular}{|l|l|l|} 
THREATS $(\mathrm{T})$ & Strategi ST & Strategi WT \\
& Menciptakan strategi & Menciptakan strategi \\
& yang menggunakan & yang meminimalkan \\
& kekuatan untuk & kelemahan dan \\
mengatasi ancaman & menghindari ancaman \\
\hline
\end{tabular}

Setelah membuat matriks SWOT dan menentukan empat alternatif strategi, manajemen kemudian harus mengambil keputusan dengan merujuk pada strategi yang diperoleh dalam matriks SWOT.

\section{Analisis TOWS (Threat, Opportunity, Weakness, Strength)}

Seiring dengan perkembangan kebutuhan manusia dan pertumbuhan teknologi dari konvensional ke digital metode analisa SWOT Matrix mulai ditinggalkan. Sebab kekuatan (internal) belum tentu dapat memenuhi peluang pasar dengan baik dan mampu menghadapi tekanan atau tantangan. Saat ini berkembang analisa TOWS yang mengedepankan faktor eksternal dibandingkan faktor internal. ${ }^{37}$ Mereka terlebih dulu mempelajari dan menginvestigasi peluang faktor-faktor eksternal, karena dianggap bersifat lebih dinamis dan bersaing Sesudah mendapatkan informasi eksternal, barulah dilakukan beberapa penyesuaian sampai perbaikan potensi internal untuk menciptakan peluang menguntungkan.

Berdasarkan analisa TOWS Matrix tersebut kemudian dilakukan 4 langkah berikutnya, yaitu, ${ }^{38}$

a. Memaksimalkan potensi atau kekuatan.

b. Memastikan kelemahan tidak membebani usaha atau kemajuan.

c. Memaksimalkan peluang yang tersedia.

d. Mengantisipasi segala bentuk tantangan \& menyediakan beberapa solusi.

Harold Koontz dan Heinz Weihrich menggambarkan matriks TOWS sebagai berikut: ${ }^{39}$

Gambar 2. Matriks TOWS

\begin{tabular}{|c|c|c|}
\hline & Internal strengths $(\mathrm{S})$ & Internal weaknesses $(\mathrm{S})$ \\
\hline $\begin{array}{c}\text { External } \\
\text { Opportunities }(\mathrm{O})\end{array}$ & \begin{tabular}{|lr}
\multicolumn{2}{|l}{ SO strategy : } \\
Maxi \\
strategi \\
berpotensi $\quad$ yang \\
\multicolumn{2}{|c|}{ sukses, memanfaatkan } \\
\end{tabular} & $\begin{array}{lr}\text { WO strategy : } & \text { Mini- } \\
\text { Maxi } & \\
\text { misalnya } & \text { strategi, } \\
\text { develpmental } & \text { untuk } \\
\text { mengatasi } & \text { kelemahan }\end{array}$ \\
\hline
\end{tabular}

37 Weihrich, H. (1982). The TOWS matrix-A tool for situational analysis. Long range planning, 15(2), 54-66.

${ }^{38}$ Proctor, T. (2000). Strategic marketing management for health management: cross impact matrix and TOWS. Journal of Management in Medicine, 14(1), 47-56. 2008),

${ }^{39}$ Heinz. W. dan Haroold Koontz, Essentials of Management seventh edition. (Tata McGraw-Hill, 


\begin{tabular}{|c|l|l|l|} 
& \multicolumn{2}{|l|}{ kekuatan lembaga } & untuk memanfaatkan \\
untuk memanfaatkan & peluang \\
& peluang & \\
\hline & ST strategy: Maxi- & WT strategy: Mini- \\
& Mini & Mini \\
External threats & misalnya, penggunaan & misalnya, penghematan, \\
$(\mathrm{T})$ & kekuatan untuk & likuidasi atau usaha \\
& mengatasi ancaman & patungan & untuk \\
& atau untuk & meminimalkan raik \\
& menghindari ancaman & kelemahan & dan \\
& & ancaman & \\
\hline
\end{tabular}
yaitu; ${ }^{40}$

Berdasarkan analisa TOWS Matrix itu juga dihasilkan 4 strategi pencapaian target,

a. SO (Aggressive Strategy): Menggunakan kekuatan internal untuk mengambil kesempatan yang ada di luar.

b. ST (Diversification strategy): Menggunakan kekuatan internal untuk menghindari ancaman yang ada di luar.

c. WO (Turn Around) - Menggunakan kesempatan eksternal yang ada untuk mengurangi kelemahan internal.

d. WT (Defensive strategy) - Meminimalkan kelemahan dan ancaman yang mungkin ada.

Analisa TOWS Matrix lebih memastikan kita dapat memperhitungkan dan memanfaatkan dengan baik setiap peluang di luar untuk peningkatan bisnis. Di saat bersamaan kita juga dapat mengetahui dan memanfaatkan potensi internal. Dengan menganalisa eksternal tersebut (TOWS Matrix) kita juga mampu mengantisipasi tantangan dari setiap perubahan eksternal, bahkan mengubahnya (tantangan) menjadi peluang baru.

\section{KESIMPULAN}

Telaah lingkungan strategis dilakukan untuk mengidentifikasi berbagai berbagai kekuatan dan kelemahan internal (internal strengths and weaknesses). Kekuatan dan kelemahan internal dilakukan dengan melakukan analisis pengembangan profil lembaga yang mencerminkan kondisi internal dan kemampuan perusahaan dan merupakan hasil analisis internal untuk mengidentivikasi tujuan dan strategi sekarang, serta memerinci kuantitas dan kualitas sumber-sumber daya lembaga yang tersedia. Profil perusahaan menunjukkan kesuksesan perusahaan dimasa lalu dan kemampuannya untuk mendukung pelaksanaan kegiatan sebagai implementasi strategi dalam pencapaian tujuan dimasa yang akan datang.

${ }^{40}$ Umar, H. (2001). Strategic management in action. Gramedia Pustaka Utama. 
Lingkungan strategis dianalisa untuk mengetahui pengaruh-pengaruh kunci serta pemilihan strategi apa yang sesuai dengan tantangan yang datangnya dari lingkungan. Dalam menerapkan teknik manajemen strategik secara baik dan berhasil, perlu dilakukan beberapa langkah pokok yang harus dilakukan. Analisa strategis dapat dilakukan dengan model analisa SWOT, TOWS ataupun Ballance Scored Card.

Tujuan analisa lingkungan strategik:

a. Untuk menyediakan kemampuan dalam menggapai masalah-masalah kritis dalam lingkungan bagi manajemen sebuah lembaga apapun.

b. Untuk menyelidiki kondisi masa depan dari lingkungan lembaga dan kemudian mencoba memasukkannya kedalam pengambilan keputusan lembaga.

c. Untuk mengenali masalah-masalah mendesak yang signifikan bagi sebuah lembaga, dan memberikan prioritas terhadap masalah tersebut, serta mengembangkan suatu rencana untuk menanganinya.

\section{DAFTAR PUSTAKA}

A. S. Wahyudi, Manajemen Strategi, (Bina Aksara, 1996), 48

Akdon, Strategik Management For Educational Management, (Bandung: Alfabeta, 2007), 107

Akdon, Strategik Management For Educational Management, 108-111

Arikunto, S. (2006). Metodelogi penelitian. Yogyakarta: Bina Aksara.

C. Williams, Manajemen, 51

Chuck Williams, Manajemen. ter. (Jakarta: Salemba Empat, 2001), 51

D. Ireland, R. E. Hoskisson \& M. A. Hitt, Manajemen Strategis : Daya Saing \& Globalisasi, Edisi ke-1, (Jakarta: Salemba Empat, 2001)

Dan Schendel dan Charles Higgins, Pengambilan Keputusan Stratejik untuk Organisasi Public dan Organisasi, (Jakarta: Grasindo, 1985)

Eddy R. Sembiring, Meraih Competitive Advantage Melalui Learning Organization. (Media Akuntansi, 2003), 52-53

Freddy Rangkuti, Analisis SWOT Teknik Membedah Kasus Bisnis, (Jakarta: PT. Gramedia Pustaka Utama, 1998), 19

G. Hamel dan K. C. Prahalad, Kompetisi Masa Depan, (Jakarta: Bina rupa Aksara, 1995)

Gugup Kismono, Perubahan Lingkungan, Transformasi Organisasional dan Reposisi Fungsi Sumber Daya Manusia. Jurnal Ekonomi dan Bisnis Indonesia, Vol 14 No.2, 1999, 62-76

Hanafi, M. (2015). Manajemen.

Heinz. W. dan Haroold Koontz, Essentials of Management seventh edition. (Tata McGrawHill, 2008),

Ignor Ansoff, Corporate Strategy, (Harmondsworth: Penguin Books, 1965)

J. Salusu, Pengambilan Keputusan Stratejik: untuk Organisasi Publik dan Organisasi Nonprofit, (Jakarta: Grasindo, 2004), 319

Jackson, S. E., Joshi, A., \& Erhardt, N. L. (2003). Recent research on team and organizational diversity: SWOT analysis and implications. Journal of management, 29(6), 801-830.

James A.F. Stoner, Manajemen. ter. (Jakarta: Erlangga, 1996) 
John M. Bryson, Strategic Planning for Public and Non Profit Organization: A Guide to Strengthening and Sustaining Organizational Achievment, (San Fransisco: JosseyBass Publishers, 1995), 55-71

Kuhlthau, C. C. (1994). Teaching the library research process. Rowman \& Littlefield.

Proctor, T. (2000). Strategic marketing management for health management: cross impact matrix and TOWS. Journal of Management in Medicine, 14(1), 47-56.

Samuel C.Certo dan Paul J. Peter, Strategic Management: A Focus on Process, (Singapore: McGraw Hill International Editions, 1990), 10-14

Stepphanie K. Marrus, Building the strategic Plan: find, analyzed, and present the right information, (USA: Wiley, 1984)

Suneki, S. (2012). Dampak globalisasi terhadap eksistensi budaya daerah. CIVIS, 2(1/Januari).

T. Hani Handoko, Manajemen, (Yogyakarta: BPFE, 1999), 62

Umam, M. K. (2017). ANALISIS LINGKUNGAN STRATEGIK DALAM CORAK PENYELENGGARAAN PENDIDIKAN ISLAM. Jurnal al Hikmah, 5(1), 1-8.

Umam, M. K. (2017, May). Strategi Alternatif Memajukan Lembaga Pendidikan Islam di Pedesaan Berbasis Sekolah Excellent Perspektif Kompetitif Kotemporer. In Proceedings of Annual Conference for Muslim Scholars (No. Seri 2, pp. 769-776).

Umam, M. K. (2018). STRATEGI INTELEKTUALISASI PROGESIFITAS MANHAJUL AL FIKR KADER AN-NAHDLIYAH.

Umam, M. K. (2018, April). Reconstruction of Integrative Islamic Education in The Transformative Profetical Education Framework. In Proceedings of Annual Conference for Muslim Scholars (No. Series 1, pp. 511-520).

Umam, M. K. (2018, February). Paradigma Pendidikan Profetik dalam Pendekatan Pembelajaran Tematik di Madrasah Ibtida'iyah. In PROCEEDING: The Annual International Conference on Islamic Education (Vol. 3, No. 1, pp. 120-132).

Umam, M. K. (2019). Peningkatan Mutu Pendidikan Melalui Manajemen Peserta Didik. Jurnal al Hikmah, 6(2), 62-74.

Umam, M. K. (2019). Penggunaan Metode Jaritmatika Dalam Meningkatkan Motivasi Belajar. Awwaliyah: Jurnal Pendidikan Guru Madrasah Ibtidaiyah, 2(1), 45-68.

Muliati, B., \& Umam, M. K. (2019). Phenomenon Of Changes In Increasing Development Of Students In Basic School. MIDA: Jurnal Pendidikan Dasar Islam, 2(1), 96-105.

Umam, M. K., \& Kediri, S. B. S. P. (2018). Rekonstruksi Pendidikan Islam Integrasi Dalam Kerangka Pendidikan Profetik Transformatif.

Umam, M. K. (2018). IMAM PARA NABI: MENELUSUR JEJAK KEPEMIMPINAN DAN MANAJERIAL NABI MUHAMMAD SAW. Jurnal al Hikmah, 6(1), 59-74.

Umar, H. (2001). Strategic management in action. Gramedia Pustaka Utama.

UU Sisdiknas No. 20. Tahun 2003

Weihrich, H. (1982). The TOWS matrix -A tool for situational analysis. Long range planning, 15(2), 54-66. 